University of Nebraska - Lincoln

DigitalCommons@University of Nebraska - Lincoln

Faculty Publications from the Harold W. Manter Laboratory of Parasitology

$10-1975$

\title{
Prevalence of Toxoplasma Antibodies in Range vs. Dairy Cattle from the Bitterroot Valley of Montana
}

Franklin Sogandares-Bernal

University of Nebraska-Lincoln

A. A. Marchiondo

Brigham Young University

Donald W. Duszynski

University of New Mexico, eimeria@unm.edu

J. K. Ward

Bitter Root Vetrinary Clinic

Follow this and additional works at: https://digitalcommons.unl.edu/parasitologyfacpubs

Part of the Parasitology Commons

Sogandares-Bernal, Franklin; Marchiondo, A. A.; Duszynski, Donald W.; and Ward, J. K., "Prevalence of Toxoplasma Antibodies in Range vs. Dairy Cattle from the Bitterroot Valley of Montana" (1975). Faculty Publications from the Harold W. Manter Laboratory of Parasitology. 121.

https://digitalcommons.unl.edu/parasitologyfacpubs/121

This Article is brought to you for free and open access by the Parasitology, Harold W. Manter Laboratory of at DigitalCommons@University of Nebraska - Lincoln. It has been accepted for inclusion in Faculty Publications from the Harold W. Manter Laboratory of Parasitology by an authorized administrator of DigitalCommons@University of Nebraska - Lincoln. 


\section{Prevalence of Toxoplasma Antibodies in Range vs. Dairy Cattle from the Bitterroot Valley of Montana}

"Natural" or unaltered foods have become a fad in recent years. This includes the drinking of unpasteurized cow's milk as well as that designated "Certified." This report is made to call attention to a high prevalence of antibodies to toxoplasma in dairy as compared with range cattle. Previous to this study, few papers have considered the breed or conditions of management of cattle sampled for toxoplasma antibodies (McIlwain, 1969, Arch Environ Health 19: 885-886; Vanderwagen et al., 1974, J Am Vet Med Assoc 164: 1034-1037).

Sera used in this study were taken at small abattoirs, and at individual ranches within a radius of approximately 15 miles from Hamilton, Montana, during 1973-74. Animals sampled (Table I) were estimated to weigh between 360 to $600 \mathrm{~kg}$, but their exact ages were unknown. Antibody titers were determined by the Sabin-Feldman dye test as modified by Frenkel and Jacobs (1958, Arch Opthalmol 59: 260-279) using the RH strain of Toxoplasma gondii, maintained by serial passage in adult CF-1, outbred, and $\mathrm{A} / \mathrm{J}$ inbred albino mice. Both positive and negative controls were included each time the dye test was performed. Titers of 1:16 and higher are regarded as significant (Feldman, 1968, N Engl J Med 279: 2431-2437) and were considered by us to represent previous or current infection.

The difference in positive titers between dairy (Holstein) and range (Angus, Angus $X$ Hereford, Hereford) animals was $>30 \%$ (Table I). Using the Chi-square test this value is significantly different $(P<0.001)$ when dairy vs. combined range cattle are compared. Differences in positive titers between range breeds were not statistically significant.

It was noted that one Angus precolostral calf sampled, but not included in the table, had a titer of 1:8, suggesting either an infection or the passage of maternal antibodies, perhaps $\mathrm{I}_{\mathrm{g}} \mathrm{G}$, through the placenta. One precolostral Hereford male calf also not included in the table exhibited a titer of 1:32.

Many ranchers keep cats in barns as mousers, and during the heavy winters in Montana the ground is frozen or covered with snow. Under these conditions feline hosts may be more likely to defecate in barns containing the dairy ani-

TABLE I. Prevalence of toxoplasma antibodies (dye test) in 130 cattle from the Bitterroot Valley of Montana.*

\begin{tabular}{|c|c|c|c|c|c|c|}
\hline \multirow[b]{2}{*}{ Breed } & \multicolumn{2}{|c|}{ Sex } & \multicolumn{4}{|c|}{ Reciprocal of Titer } \\
\hline & $\mathbf{F}$ & $\mathbf{M}$ & $<16$ & $16-64$ & $\geqslant 128$ & $\% \geqslant 16$ \\
\hline Angus & 46 & 3 & 32 & 9 & 8 & 35 \\
\hline Angus $\times$ Hereford & 13 & 0 & 9 & 3 & 1 & 31 \\
\hline Hereford & 24 & 15 & 29 & 7 & 3 & 27 \\
\hline Holstein & 24 & 5 & 11 & 7 & 11 & 62 \\
\hline \multicolumn{7}{|l|}{ Totals } \\
\hline No. & 107 & 23 & 81 & 26 & 23 & 49 \\
\hline$\%$ & 82 & 18 & 62 & 20 & 18 & 38 \\
\hline
\end{tabular}

* All numbers rounded out to nearest whole number. 
mals, thereby contaminating their food or water with sporocysts of Sarcocystis or oocysts of Toxoplasma. Although environmental temperatures in the barns were not sampled to determine if oocyst development is possible during winter conditions, a barn might serve as a habitat for a concentrated rodent $\leftrightarrow$ feline $\rightarrow$ bovine cycle. Controlled seasonal population studies of these cycles in barns are indicated.

Particular attention is called to the fact that "Certified" herds are not examined for toxoplasma by regulatory agencies. Since toxoplasma may be recovered from the milk of infected animals (Cole et al., 1953, Proc 15th Int Vet Congr Part I, p. 401-405), and in view of the high prevalence of Toxoplasma antibodies in these dairy cattle, the drinking of "Certified" or unpasteurized milk from them may pose a risk to certain human populations.
We wish to thank Dr. J. K. Frenkel, Department of Pathology and Oncology, The University of Kansas Medical Center, Kansas City, for instructing one of us (DWD) in his laboratory in use of the dye test and for supplying the RH strain of $T$. gondii. This research was supported in part by a research grant from the Brown-Hazen Fund of Research Corporation, 1290 Bayshore Highway, Burlingame, California 94010.

F. Sogandares-Bernal, A. A. Marchiondo, * D. W. Duszynski, ${ }^{*}$ and J. K. Ward, $\dagger$ Department of $\mathrm{Mi}$ crobiology, The University of Montana, Missoula 59801 (current address: Department of Biology, Southern Methodist University, Dallas, Texas 75275). *Department of Biology, The University of New Mexico, Albuquerque, 87131, and †Bitter Root Veterinary Clinic, Hamilton, Montana 59840 